\title{
STRUCTURAL ANALYSIS OF MANGROVE COMMUNITIES ON THE CENTRAL QUEENSLAND COASTLINE
}

\author{
by \\ P. SAENGER ${ }^{1)}$ and J. ROBSON ${ }^{2)}$
}

\begin{abstract}
The mangrove communities of the Central Queensland coastline are structurally and floristically intermediate between the relatively simple, temperate mangrove communities to the south, and the more complex and luxuriant communities to the north. Climatically the central Queensland coastline is subtropical with a low $(1011 \mathrm{~mm})$ annual rainfall, falling mainly in the summer months; evaporation rates are high, particularly in winter. As a result of a four-metre tidal range and a gentlysloping depositional coastline, the areal extent of mangroves is large and most topographic and physiognomic types are represented. Twelve species of mangroves occur in the study area and although zonation is recognizable, the zones are neither constant nor discrete. In the Port Curtis area, three large plots $\left(500 \mathrm{~m}^{2}\right.$ have been established in which all mangroves have been numbered and tagged since January 1975. The results of the initial investigation of the plots are presented together with some of the changes noted on re-examination after 12 months.
\end{abstract}

\section{INTRODUCTION}

The mangrove communities of the Central Queensland coastline are structurally and floristically intermediate between the relatively simple temperate communities to the south, and the more complex and luxuriant communities to the north (SAENGER et al. 1976). Despite the fact that the Gladstone area is destined as an industrial growth centre, no detailed studies of the extensive mangrove communities of this area have as yet been carried out. Although a number of Australian mangrove species have been studied under culture conditions (CONNOR 1969; ClARKE and HANNON 1970; MCMillan 1975a) there is little information on species performance in the field. Since as WATSON (1928) has stated, it is the ability to regenerate itself and not merely to exist that is important, the collation of field data on growth rates, mortality rates and establishment rates particularly of seedlings, is fundamental to an understanding of mangrove distribution in any area.

1. c/o The Southern Electric Authority of Queensland, Sciences Section, P.O. Box 403, Brisbane.

2. The Southern Electric Authority of Queensland, Technical Programming Section, P.O. Box 403, Brisbane. 


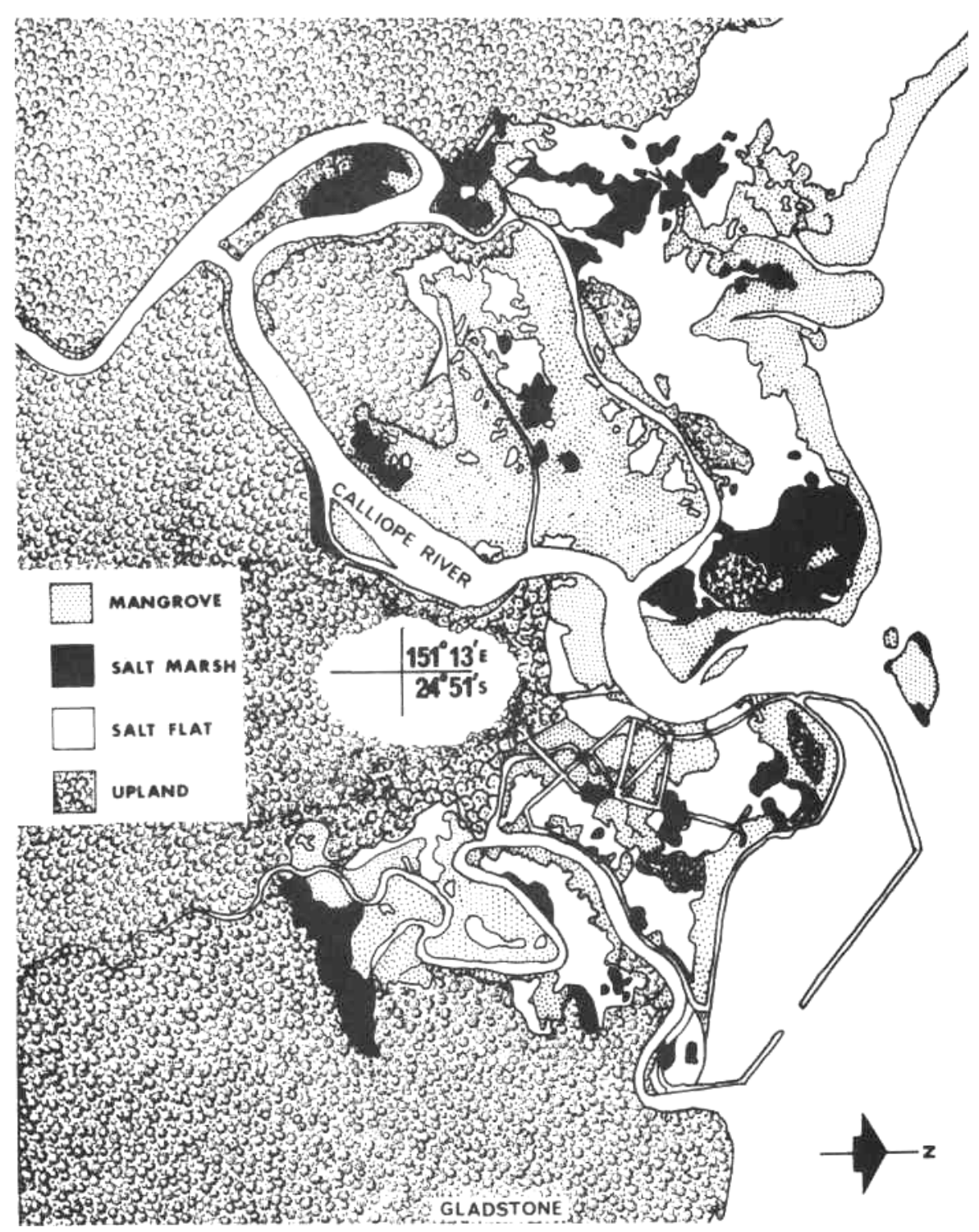

Figure 1. Locality map of study area showing the distribution of mangroves, salt marsh and the vegetation-free salt flats. 


\section{THE STUDY AREA}

The study area (Fig. 1) comprises a large submerged valley formed by rising sealevels in the Quaternary (CONAGHAN 1966). An outer series of barrier islands protects the enclosed water and forms a large area of low energy coastline. Three rivers drain into the bay - the Boyne River, Calliope River and Auckland Creek. The course of the Calliope River was incised by fluvial activity prior to submergence in the area (HOFMANN 1971).

Draining a hinterland of mostly argillaceous rock, the Calliope River carries a large stream sediment load of predominantly mud. CONAGHAN (1966) who studied the sedimentary processes in Port Curtis, concludes that tidal circulation dominates the hydrographic features of the area. The scouring effects of tidal currents (tidal range is up to 4.2. metres), in particular at ebb tide, maintains a relatively stable balance between deposition and erosion in tidal channels including the creeks in the mud and mangroveflats. The mud content of these sediments is highest in the more remote low-energy portions of the peripheral shoals, occurring particularly on the leeward sides of physiographic features.

Climatically the Port Curtis coastline is subtropical with an average annual rainfall of $1011 \mathrm{~mm}$ falling over an average 108 raindays per year. Rainfall data for Gladstone, together with other meteorological parameters is given in Table I. During the summer months, winds are predominantly easterly becoming more southerly during winter. The number of cyclones passing within $5^{\circ}$ latitude and longitude of Gladstone is 9.2 per 10 years with over 50\% occurring in the months of February and March. Cyclones causing structural damage in Gladstone are recorded for March 1949, January 1967, April 1972 and February 1976.

Water temperatures in the Calliope River in 1975 ranged from a maximum of $29^{\circ} \mathrm{C}$ in January - February to a minimum of $17^{\circ} \mathrm{C}$ in June July. Salinities for the same period showed concentrations of $35.5 \%$ during winter and 20\%o during the wet summer months with occasional salinities as low as 5\%o during flood conditions.

\section{GENERAL ACCOUNT OF THE MANGROVE VEGETATION}

As a result of a large tidal range, a high stream sediment load of mud and a gently-sloping depositional shoreline, the areal extent of mangroves is large and most topographic and physiognomic types are represented. The distribution of mangroves, vegetation-free high tidal flats (FOSBERG 
Table I. Meteorological data for Gladstone, Central Queensland

\begin{tabular}{|l|r|r|c|}
\hline & $\begin{array}{r}\text { Annual } \\
\text { Mean }\end{array}$ & $\begin{array}{r}\text { January } \\
\text { Mean }\end{array}$ & $\begin{array}{l}\text { July } \\
\text { Mean }\end{array}$ \\
\hline $\begin{array}{l}\text { Solar Radiation } \\
\left(\text { Cal cm }^{-2} \text { day }^{-1}\right)\end{array}$ & 460 & 545 & 340 \\
$\begin{array}{l}\text { Precipitation } \\
(\mathrm{mm})\end{array}$ & 1011 & 182 & 45 \\
$\begin{array}{l}\text { Pan Evaporation } \\
(\mathrm{mm})\end{array}$ & 1416 & 147 & 90 \\
$\begin{array}{l}\text { Surface Runoff } \\
(\mathrm{mm})\end{array}$ & 212 & 28 & 18.5 \\
$\begin{array}{l}\text { Air Temperature } \\
(\%)\end{array}$ & 6.23 & $28.0 *$ & $0.71^{* *}$ \\
$\begin{array}{l}\text { River Discharge } \\
\left(\mathrm{m}^{3} \text { sec }^{-1}\right.\end{array}$ & 23 & \\
\hline
\end{tabular}

* February Mean

** August Mean

1961) and tidal herblands is shown in Fig. 1. Twelve species of mangroves occur in the area and these are given with commonly associated species in Table II.

Table II. Mangroves and associated plant species of the Port Curtis area.

\section{VERBENACEAE}

Avicennia marina (FORSK.) VIERH. var. australasica (WALP.) MOLDENKE Avicennia eucalyptifolia ZIP. ex MIQ. *

\section{RHIZOPHORACEA}

Rhizophora stylosa GRIFF.

Bruguiera gymnorhiza (L.) LAM. Ceriops tagal var. australis C.T. WHITE.

\section{COMBRETACEAE}

Lumnitzera racemosa WILLD.

* Although both the rough-barked $A$. marina and the smoothbarked A. eucalyptifolia occur, we consider these as ecotypes of the one species (A. marina) and treat them as such. 
Table II. ( contd )

EUPHORBIACEAE Excoecaria agallocha L.

\section{MELIACEAE}

Xylocarpus australasicum RIDL.

\section{MYRSINACEAE}

Aegiceras corniculatum (L.) BLANCO.

\section{MYRTACHEAE}

Osbornea octodonta F. MUELL.

PLUMBAGINACEAE Aegialitis annulata R. BR.

ACANTHACEAE Acanthus ilicifolius L.

\section{PTERIDACEAE}

Acrostichum speciosum WILLD.

\section{LORANTHACEAE}

Amyema mackayense (BLAKELY) DANS..ssp. mackayense

\section{AIZOACEAE}

Sesuvium portulacastrum L.

\section{CHENOPODIACEAE}

Arthrocnemum halocnemoides NEES var. pergranulatum J.M. BLACK. Arthrocnemum leiostachyum (BENTH.) PAULSEN.

Salicornia quinqueflora BUNGE ex UNG. STERNB.

Suaeda spp.

Salsola kali L. 
Table II. ( contd. )

\section{POACEAE}

Sporobolus virginicus (L.) KUNTH.

\section{MYOPORACEAE}

Myoporum acuminatum R. BR.

Mangrove vegetation extends over a vertical range from approximately MHWN to HWS levels. Along the shores of Port Curtis and including the islands near the mouth of the Calliope River, a tall fringe forest (7 m high) occurs while within the Calliope River as well as the smaller creeks, the type of mangrove communities are more variable and not well developed in terms of height or density.

Although zonation of the mangroves is recognizable, the patterns are somewhat obscured by the generally irregularly sloping shorelines and other topographical irregularities. Species composition of the various zones and zone sequences are variable; for example the outer fringe may consist of pure stands of Rhizophora, pure stands of Avicennia or mixed stands of either of these mangroves in combination with Aegiceras.

Two localised features of the Port Curtis mangrove communities are the marked abundance of Rhizophora, already commented on by FLINDERS (1814) during his visit to the area in 1802. The second feature is the scarcity of Bruguiera which occurs in small stands throughout the area but is relatively rare and does not form a mixed Bruguiera forest as in other east coast localities (MACNAE 1966; JonEs 1971). The susceptibility of Bruguiera to cyclone damage my be partially responsible.

\section{PERMANENT PLOTS}

Three large plots were selected from air-photographs for more detailed study. Topographically the plots are similar but they are located in a riverine environment with a seasonally high freshwater discharge (plot 1), an inlet environment with a small catchment area (plot 2) and an island environment with minimal freshwater influence (plot 3). Since it seemed desirable to include all vegetational zones in each plot, the length of each plot was determined by the breadth of the area colonised by mangroves. As the 
plots are placed at right angles to the shoreline, they can be considered as 10 -metre-wide transects through the entire vegetational sequence.

Within each plot all mangroves were identified, their height and $\mathrm{GBH}$ were measured, positional co-ordinates were determined and each specimen was numbered with an aluminium tag. The microtopography of each plot was determined by levelling and a datum peg in each plot was related to the Gladstone Harbour Datum. Tidal inundation was calculated from the continuous tide recordings of the Gladstone Harbour Board. Surface soil samples (270 cc) were taken on a grid pattern within each plot and total chlorides (grams) were determined for each sample. An identical grid pattern was used to describe soil types and texture.

A programme was used to validate data about the trees and to store this data on a disc file. The data stored for each tree includes tree number, tree species, positional co-ordinates, height, $\mathrm{GBH}$, tidal level, soil salinity (as total chloride), soil type and soil texture. Data for each succeeding year is added to the data held on file. Another programme consists of retrieval functions allowing data retrieval on a) a particular tree by number or position b) information about a group showing some property and c) information about the variation in a property common to a group of trees, Contour plots of tide levels and soil salinity can be superimposed on the vegetation plots. All programmes are written in ICL FORTRAN and are run on an ICL 1903 computer.

\section{RESULTS AND DISCUSSION}

The analyses of plots $1-3$ have been presented as transects in Figs. 2 - 4 to elucidate mangrove distribution in relation to gradients of soil salinity and height above datum. Canopy heights along the transects (Fig. 5) show the generally low profiles of the mangroves.

Zonational sequences are discernible (Figs. 2-4) but they are neither constant nor distinct. No significant difference in distribution pattern was observed between mature trees and seedlings. A similar variation in the vegetational zones has been described from Bustard Bay, $60 \mathrm{~km}$ south of the present study area (SHANCO and TIMmins 1975) but the causative factors were not identified. The upper and lower limits of the mangroves in relation to height above datum and soil salinity are given in Table III, but these data only partially explain the zonational distribution of the genera. 


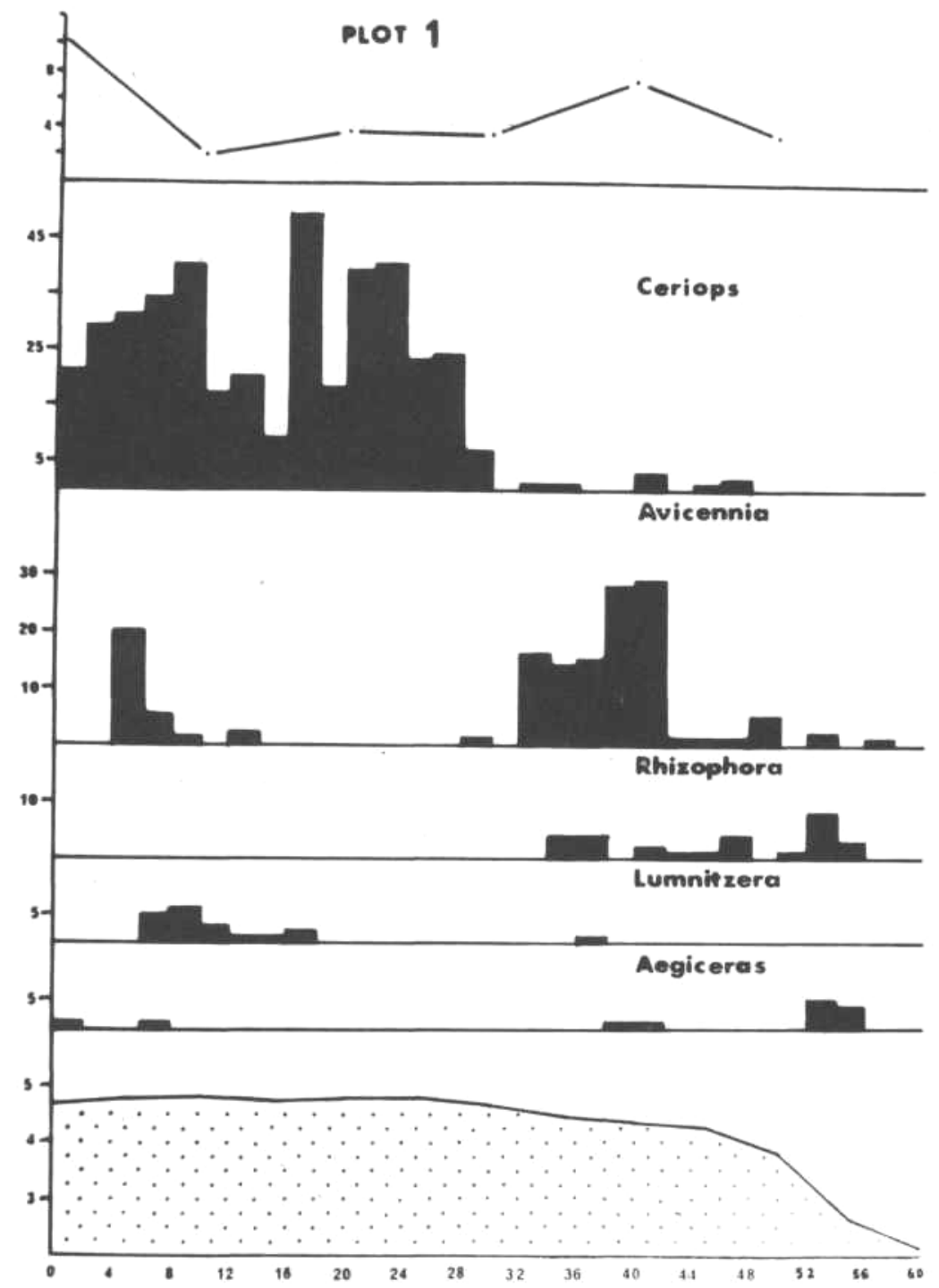

Figure 2. Distribution of mangroves along plot 1 . Top Soil salinity as gCl/270 cc soil; Middle number of mangroves per $20 \mathrm{~m}^{2}$; Bottom - substrate height above datum in metres. 


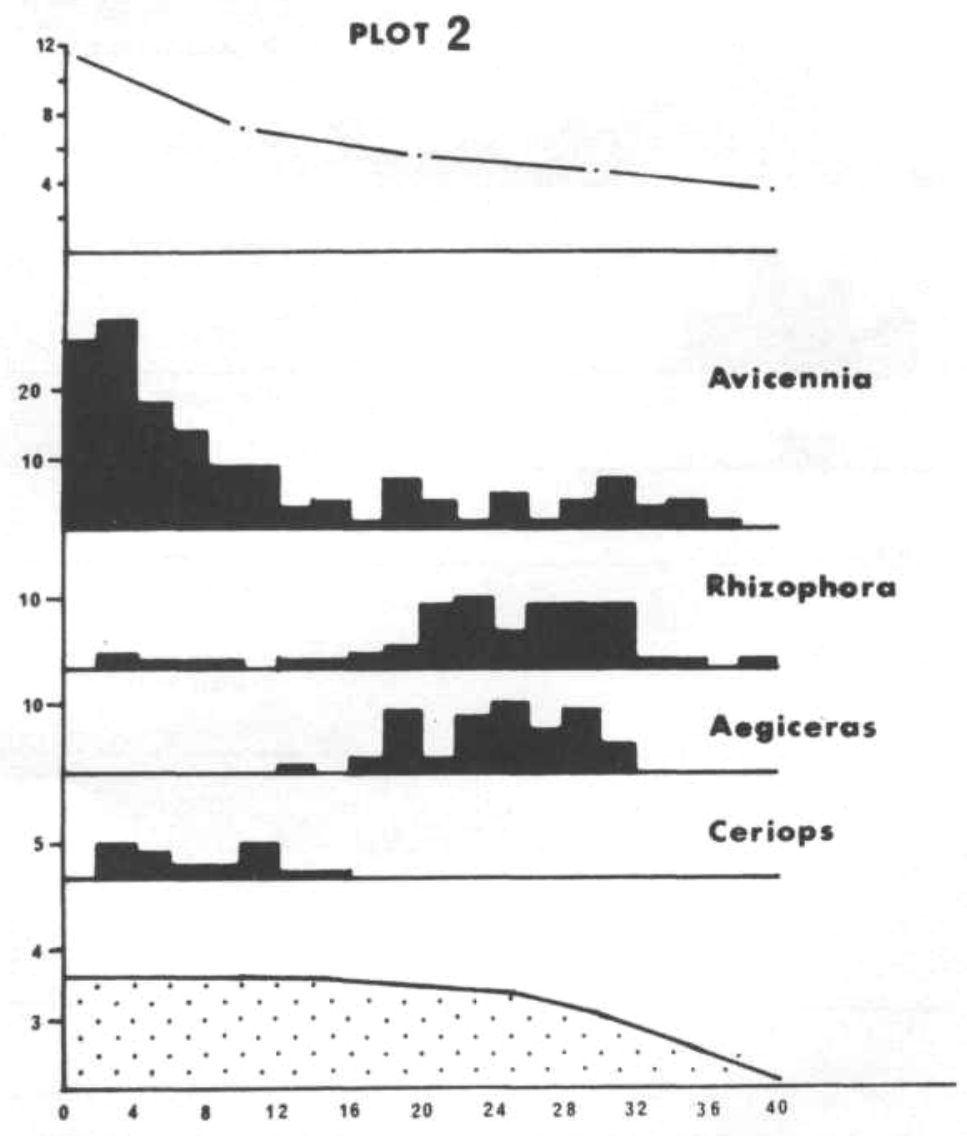

Figure 3. Distribution of mangroves along plot 2. Top - Soil salinity as gCl/270 cc soil; Middle number of mangroves per $20 \mathrm{~m}^{2}$; Bottom - substrate height above datum in metres. 


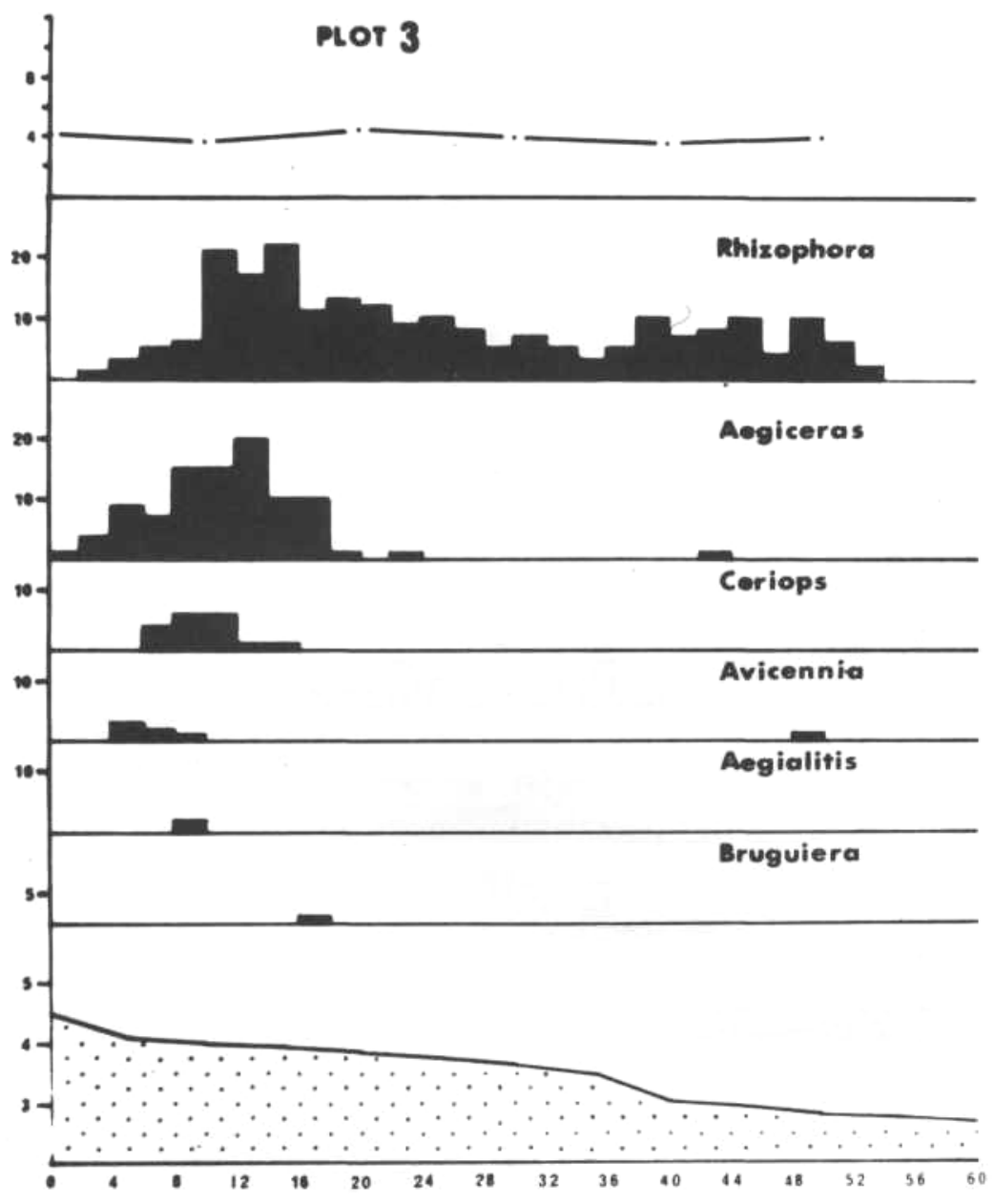

Figure 4. Distribution of mangroves along plot 3. Top - Soil salinity as gC1/270 cc soil; Middle number of mangroves per $20 \mathrm{~m}^{2}$; Bottom - substrate height above datum in metres. 


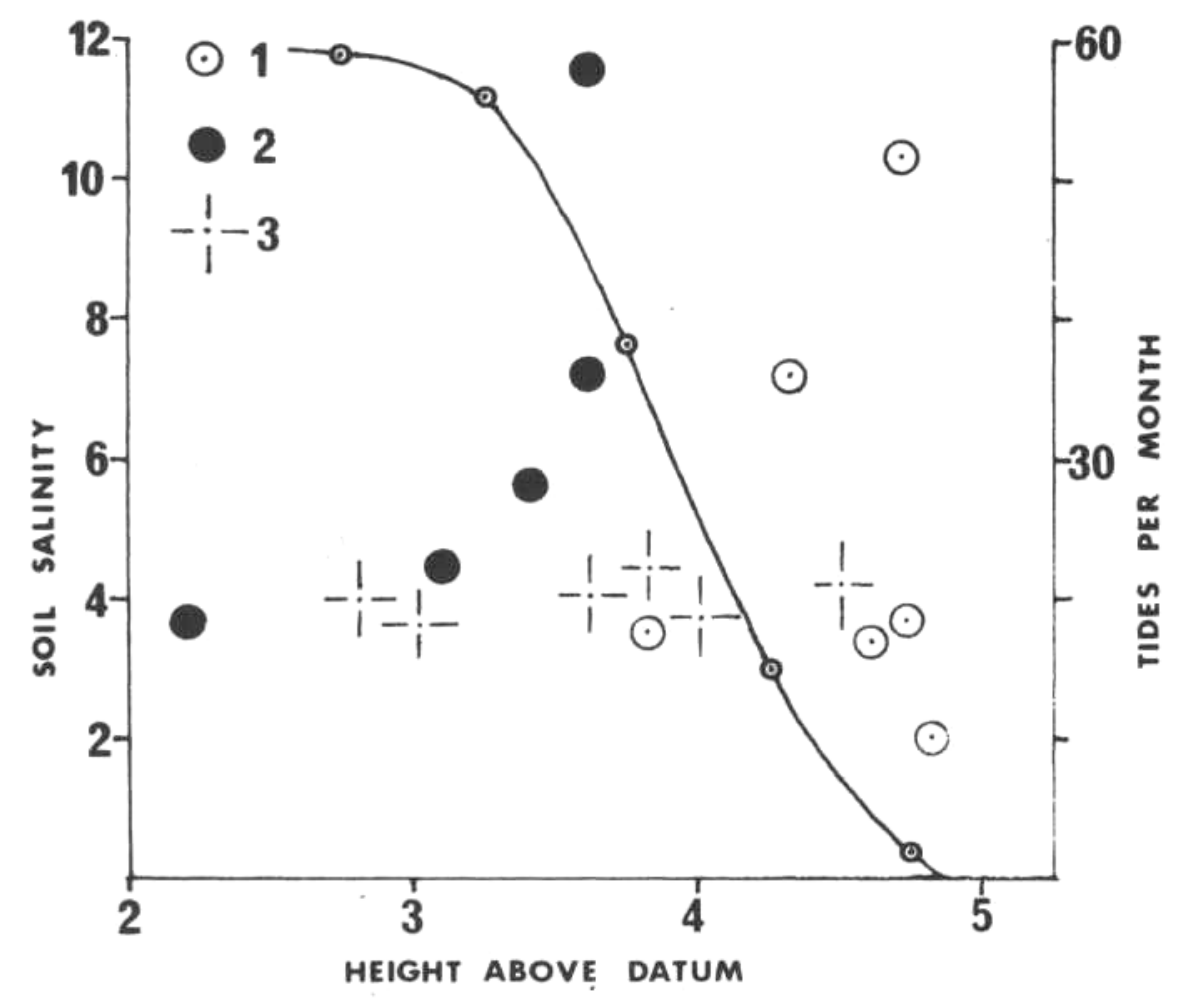

Figure 5. Relationships between number of tides per month and the height above datum (metres) and the soil salinity $\left(\mathrm{gCl}^{-} / 270 \mathrm{cc}\right.$ soil) of plots $1-3$ and height above datum.

A number of edaphic factors also appear to be involved; the relationship of the height- above datum to the number of tides per month and the soil salinities in plots $1-3$ (Fig. 6) is a complex one and differs in each plot. In plot 2 where the substrate is a uniformly firm clay, soil salinity increases with height above datum. In plot 3 where the substrate is coarser (more pervious) throughout, no apparent changes in soil salinity were observed with height above datum. In plot 1 hard clays predominate but no pattern in soil salinity is apparent. However at $4.8 \mathrm{~m}$ above datum, reached by an average of only one tide per month, the soil salinity is approximately half that of seawater (Lumnitzera occurs at this height above datum). Thus although a general increase in soil salinity with increasing height above datum (decreasing tidal inundation) would be expected, soil type and texture appears to substantially alter this tendency. Consequently depending on the soil type, substantially different soil salinities can occur at identical heights above datum. 
Table III. Upper and lower limits of mangroves in plots $1-3$ in relation to height above datum (m.) and soil salinity (g./270 cc).

\begin{tabular}{|c|c|c|c|}
\hline & Plot & Ht. above datum & Soil salinity \\
\hline & No. & $\mathrm{U}$ & $\mathrm{L}$ \\
\hline \multirow[t]{3}{*}{ Avicennia } & 1 & $4.8-2.2$ & $6.8-2.2$ \\
\hline & 2 & $3.6-2.4$ & $11.6-3.8$ \\
\hline & 3 & $4.2-2.8$ & $4.0-3.8$ \\
\hline \multirow[t]{3}{*}{ Rhizophora } & 1 & $4.5-2.5$ & $4.2-3.6$ \\
\hline & 2 & $3.6-2.4$ & $10.2-3.8$ \\
\hline & 3 & $4.5-2.8$ & $4.1-3.8$ \\
\hline \multirow[t]{3}{*}{ Aegiceras } & 1 & $4.7-2.5$ & $10.2-3.3$ \\
\hline & 2 & $3.6-2.9$ & $7.0-4.2$ \\
\hline & 3 & $4.5-3.0$ & $4.2-4.0$ \\
\hline \multirow[t]{3}{*}{ Ceriops } & 1 & $4.7-4.0$ & $10.2-4.0$ \\
\hline & 2 & $3.6-3.5$ & $10.2-6.0$ \\
\hline & 3 & $4.1-3.9$ & $4.2-4.0$ \\
\hline Lumnitzera & 1 & $4.8-4.7$ & $4.3-2.0$ \\
\hline Bruguiera & 3 & 3.9 & 4.0 \\
\hline Aegialitis & 3 & 4.1 & 3.8 \\
\hline
\end{tabular}

Soil texture is known to modify the soil salinity tolerance of Avicennia germinans (L.) LAN. (MCMILLAN 1975b), with a high clay content enhancing survival under hypersaline conditions. Soil types in the plots were classified as mud (little clay), clay, sand or any combination of these. In addition their texture and degree of waterlogging were recorded as soft (liquified, waterlogged), firm (support weight but leave footprints, water content at field capacity) and hard (support weight and leave no footprints, hard crust, water content below field capacity). These soil texture data are combined with soil salinities and heights above datum in Table IV to permit an ecological characterisation of the mangroves in the study area.

These characterisations give some insight into the factors responsible for the variable zonation patterns (cf. THOM et al. 1975); on depositional areas such as the convex banks of meanders, prograding mudflats, where soft muds occur in the outer zone, Rhizophora comprises the outer fringe. In areas of moderate wave action where sediments tend to be coarser e.g. 
STRUCTURAL ANALYSIS OF MANGROVE COMMUNITIES
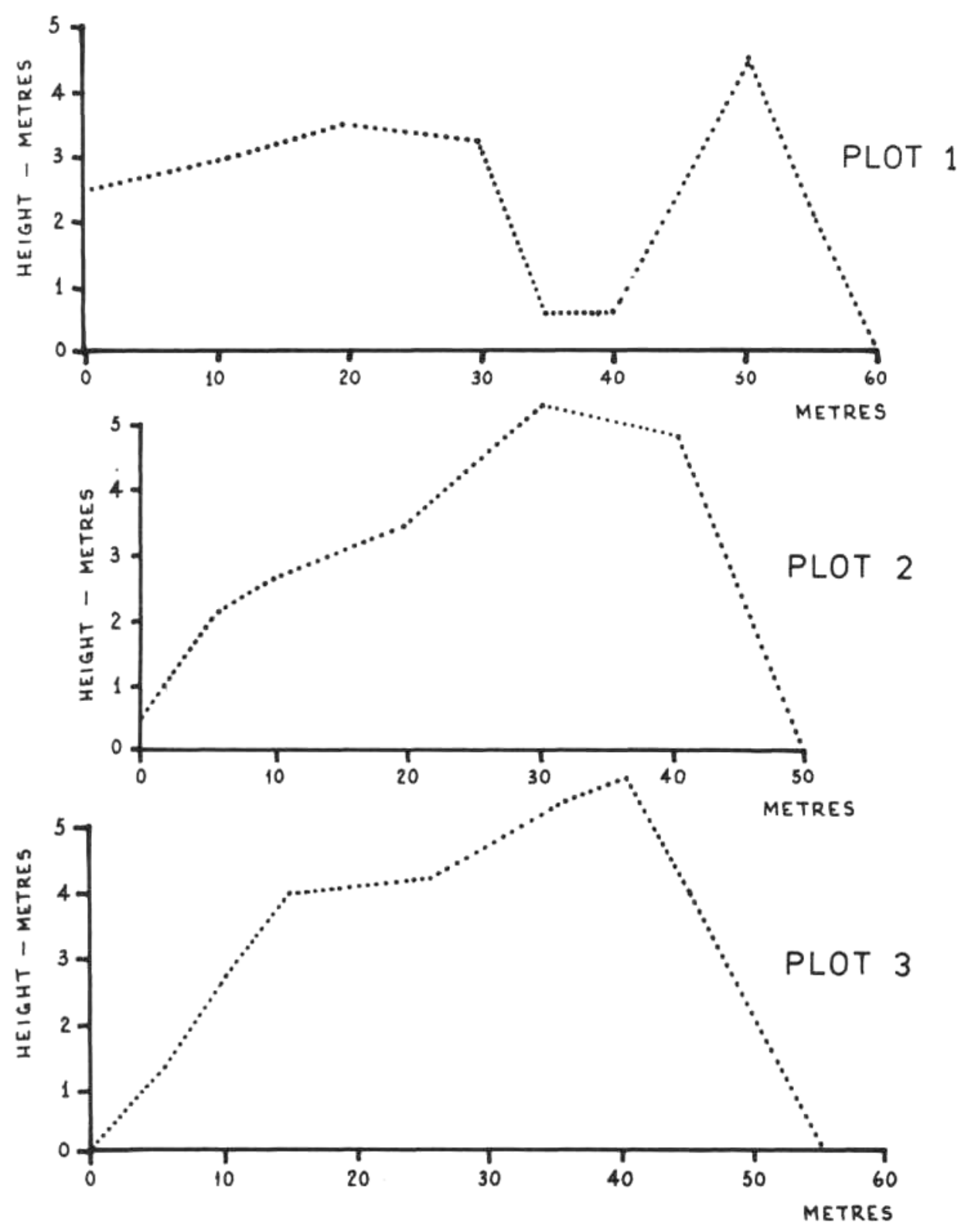

ligure 6. Average canopy height along plots $1-3$. (metres) 
Table IV. Ecological characterization of mangroves in Plots $1-3$.

\begin{tabular}{|c|c|c|c|}
\hline & Tidal Range & $\begin{array}{l}\text { Soil Salinity } \\
\text { Range }\end{array}$ & $\begin{array}{l}\text { Soil Type and } \\
\text { Texture }\end{array}$ \\
\hline Avicennia & $\begin{array}{l}\text { Throughout } \\
\text { entire range }\end{array}$ & $\begin{array}{l}\text { Throughout } \\
\text { entire range }\end{array}$ & $\begin{array}{l}\text { Firm mud or hard } \\
\text { clay }\end{array}$ \\
\hline Rhizophora & $\begin{array}{l}\text { Throughout } \\
\text { entire range }\end{array}$ & $\begin{array}{l}\text { Throughout } \\
\text { entire range }\end{array}$ & $\begin{array}{l}\text { Soft mud or firm } \\
\text { muddy sand }\end{array}$ \\
\hline Ceriops & $\begin{array}{l}\text { From Spring to } \\
\text { extreme Spring } \\
\text { high tides }\end{array}$ & $\begin{array}{l}\text { At high salinity } \\
\text { range }\end{array}$ & Hard clay \\
\hline Aegiceras & $\begin{array}{l}\text { From Neap to } \\
\text { Spring high } \\
\text { tides }\end{array}$ & $\begin{array}{l}\text { Not at either } \\
\text { extreme of range }\end{array}$ & $\begin{array}{l}\text { Soft mud or firm } \\
\text { muddy sand }\end{array}$ \\
\hline Lumnitzera & $\begin{array}{l}\text { At upper tidal } \\
\text { limit }\end{array}$ & $\begin{array}{l}\text { At low salinity } \\
\text { range }\end{array}$ & Firm clay \\
\hline Aegialitis & $\begin{array}{l}\text { Insufficient } \\
\text { data }\end{array}$ & $\begin{array}{l}\text { Insufficient } \\
\text { data }\end{array}$ & $\begin{array}{l}\text { Muddy sand } \\
\pm \text { gravel }\end{array}$ \\
\hline Bruguiera & Insufficient data & Insufficient data & Muddy sand \\
\hline
\end{tabular}

muddy sand, Rhizophora also comprises the outer fringe. On the other hand where soft muds are not accumulating or on concave banks of meanders where fluvial erosion is cutting into hard clay deposits, Avicennia comprises the outer fringe. At upstream localities or near drainage lines where salinities are somewhat lower, the outer fringe can be comprised of either Rhizophora or Avicennia in combination with Aegiceras.

In the study area Lumnitzera distribution appears to be solely determined by soil salinity while that of Ceriops coincides with the occurrence of raised and weathered hard clay deposits. Those factors responsible for the sharp demarcation between Ceriops and the vegetationfree salt flats, are unclear at present but soil salinities and the weathering properties of the salt flat deposits (COLEMAN et al. 1966) are undoubtably involved.

RABINOWITZ (1975) working with four species of mangroves in $\mathrm{Pa}-$ nama, showed that the seedlings of each genus grew equally well in each of the different vegetational zones and she concluded that the habitat division of those genera was not controlled by physiological preference 
Table V. Percentage survival of trees and seedlings and numbers of new seedlings for January 1975 - 1976. Numbers of dead specimens are in parenthesis. (Seedlings are taken as less than $0.5 \mathrm{~m}$ in height except for Aegiceras and Aegialitis where $0.2 \mathrm{~m}$ is taken as limiting height).

\begin{tabular}{|c|c|c|c|c|c|c|c|c|c|}
\hline \multirow[b]{3}{*}{ Avicennia } & \multicolumn{3}{|c|}{ \% Tree survival } & \multicolumn{3}{|c|}{ \% Seedling survival } & \multicolumn{3}{|c|}{$\begin{array}{l}\text { No. new } \\
\text { seedlings }\end{array}$} \\
\hline & 1 & 2 & 3 & 1 & 2 & 3 & 1 & 2 & 3 \\
\hline & $100 \quad(0)$ & $\begin{array}{ll}100 \quad(0) \\
\end{array}$ & $100 \quad(0)$ & 75,2 (31) & $84.1 \quad$ (7) & 50. $0(1)$ & 2 & 2 & - \\
\hline Rhizophora & $96.4(1)$ & 98. 3 (1) & '89. 2 (14) & $50.0(6)$ & $100 \quad(0)$ & 19. 4 (75) & - & 1 & 5 \\
\hline Ceriops & 98. 7 (5) & 100 & 87. 5 (2) & $65.1(15)$ & 100 & $100 \quad(0)$ & 4 & - & - \\
\hline Aegiceras & 88. 9 (1) & 100 & 98. 8 (1) & 100 & (1) & 91. 7 (1) & - & - & 9 \\
\hline Bruguiera & - & - & - & & - & 100 & - & - & - \\
\hline $\begin{array}{l}\text { Lumnitzera } \\
\text { Aegialitis }\end{array}$ & $100 \quad(0)$ & 一 & $\begin{array}{r}- \\
100\end{array}$ & 100 & 一 & - & - & - & - \\
\hline
\end{tabular}


but possibly results from a tidal sorting of the variously sized propagules. These findings indicate that seedling performance need not reflect adult performance under the same physiological conditions. Hence data on the differing rates of establishment, survival and growth of both seedlings and adults are important in understanding species composition of the community.

A summary of seedling and tree survival and establishment for a oneyear period is given in Table $\mathrm{V}$ and shows low mortality amongst adults but significant mortalities amongst seedlings of Avicennia (plot 1) and Rhizophora (plot 3). The overall growth performance of all species shows that a large proportion of the seedlings show little or no growth - the data for Ceriops from plot 1 is illustrated in Fig. 7. Presently we are analysing these growth data in relation to soil salinity, inundation frequency, canopy cover and vegetation zone in an attempt to identify those factors correlated with growth rates particularly of those seedlings growing sub-optimally. 
STRUCTURAL ANALYSIS OF MANGROVE COMMUNITIES

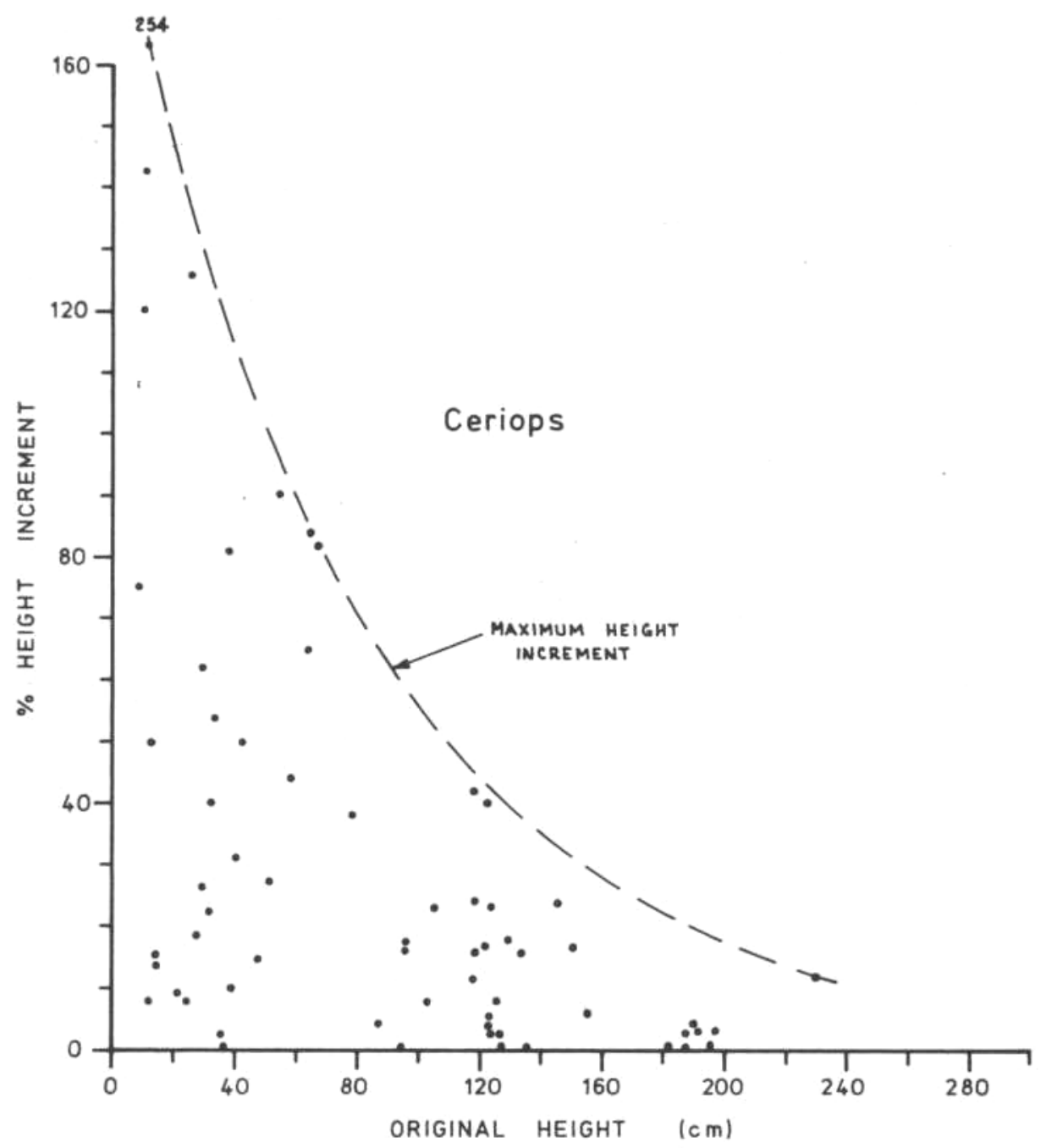

1'igure 7. Plot 1 - One year growth increments $(\%)$ versus original height $(\mathrm{cm})$ for Ceriops tagal. 


\section{ACKNOWLEDGEMENTS}

We thank Mr. L. STONES, S.E.A.Q. Gladstone, for surveying and levelling of the plots, Mr. J. EWALD, S.E.A.Q. Brisbane, for assistance and helpful discussions on many occasions and Prof. R.L. SPECHT, University of Queensland Botany Department, for helpful comments on the first draft.

The field assistance of Mr. S. PARISH and Mr. J. MOVERLEY is gratefully acknowledged.

For permission to publish this information, we thank The Southern Electric Authority of Queensland.

\section{REFERENCES}

Clarke, L.D. and N. J. HANNON 1970. The mangrove swamp and salt marsh communities of the Sydney district. Ill Plant growth in relation to salinity and waterlogging. J. Ecol. 58 : $351-369$.

Coleman, J., S.M. Gagliano and W.G. Smith 1966. Chemical and physical weathering on saline high tidal flats, North Queensland, Australia. Bull. Geol. Soc. Amer. 11 : 205 - 206.

Con A GH AN, P.J. 1966. Sedimentary processes in Gladstone Harbour, Queensland. Old. Univ. Occ. Pap. Dept. Geol 4 : 1 - 52.

ConNor, D.J. 1969. Growth of grey mangrove (Avicennia marina) in nutrient culture. Biotropica $1: 36-40$.

FLINDERS, M. 1814. A voyage to Terra Australis. G. and W. Nicol. London.

Fosberg, F.R. 1961. Vegetation-free zone on dry mangrove coasts. U.S. Geol. Surv. Prof. Pap. 424-D, pp. 216 - 218.

HOFMANN, G.W. 1972. Geological reconnaissance of a proposed power station site at Gladstone, Central Queensland. Geol. Surv. Qld., Dept. of Mines, Rep. No. 72, pp. 1 - 10.

JoNES, W.T. 1971. The field identification and distribution of mangrove in Eastern Australia. Qld. Natur. 20:35 - 51 .

Macnae, W. 1966. Mangroves in eastern and southern Australia. Aust. J. Bot. 14 :67 - 104.

McMillan, C. 1975a. Adaptive differentiation to chilling in mangrove populations. Proc. Inter. Symp. Biol. Mangt. Mangroves, Vol. I, pp. 62 - 68.

MCMillan, C. 1975b. Interaction of soil texture with salinity tolerances of Avicennia germinans (L.) LAM. and Laguncularia racemosa (L.) GAERTN. f. from North America. Proc Inter, Symp. Biol. Mangt. Mangroves, Vol. II, pp. 561 - 568.

Rabinowitz, D. 1975. Planting experiments in mangrove swamps of Panama. Proc. Inter. Symp. Biol. Mangt. Mangroves, Vol. I, pp. 385 - 393.

SAENGer, P., MM. SPECHT and V.J. ChAPMAN 1976. Mangrove and coastal salt-marsh communities in Australasia. In : Ecosystems of the World. Vol. I Wet Coastal Formations. Elsevier Publ. Co., Amsterdam, pp. 293 - 345.

Shanco, P. and R Timmins 1975. Reconnaissance of southern Bustard Bay tidal wetlands. Operculum $4: 149$ - 154.

Thom, B.G., L.D. Wright and J.M. ColEman 1975. Mangrove ecology and deltaic-estuarine geomorphology : Cambridge Gulf-Ord River, Western Australia. J. Ecol. 63 : 203 - 232.

WAtson, J.G. 1928. Mangrove forests of the Malay Peninsula. Malay. For. Rec. $6: 1$ - 275. 